\title{
MODEL PARTISIPASI PETANI LAHAN KERING DALAM KONSERVASI LAHAN
}

\author{
Suwarto $^{1}$, Suwarto ${ }^{2}$, dan Sapja Anantanyu ${ }^{1}$ \\ ${ }^{1}$ Program Studi Agribisnis Fakultas Pertanian Universitas Sebelas Maret Surakarta \\ 2 Program Studi Agroteknologi Fakultas Pertanian Universitas Sebelas Maret Surakarta \\ Jalan Ir. Sutami 36 A Kentingan Surakarta \\ E -mail: suwar_uns@yahoo.co.id
}

Diterima 19 Desember 2011 / Disetujui 2 Agustus 2012

\begin{abstract}
The study intends to describe the participation of farmers in the dryland crop based Land Conservation Index (LCI), describes the factors that affect the implementation of land conservation, and develop models to improve the participation of farmers in land conservation. Research carried out in Sub DAS upstream of Solo river. All of the food crop farmers from the Pundung villages totaling 68 family heads as respondents. The results of a study of farmers in conserving land at a moderate level. Model to improve the implementation of land conservation is increasing: land area, ownership ruminants, a family member who worked, and level of education, and empowerment to increase participation in land conservation in the parameter is still low, namely: planting plants to strengthen terracing, mulching or manure, planting annual crops on sloping land, crop rotation, and a sense of responsibility of farmers.
\end{abstract}

Keywords: models of participation, conservation, food crops farm, dry land

\begin{abstract}
Abstrak: Penelitian bermaksud mendiskripsikan partisipasi petani tanaman pangan lahan kering dalam konservasi lahan berdasarkan Indeks Kegiatan Konservasi (IKK), menjelaskan faktor-faktor yang mempengaruhi pelaksanaan konservasi lahan, dan menyusun model untuk meningkatkan partisipasi petani dalam konservasi lahan. Penelitian dilaksanakan di Sub DAS Solo hulu. Semua petani tanaman pangan dari desa Pundung yang berjumlah 68 Kepala keluarga dijadikan responden. Hasil penelitian memperlihatkan para petani melakukan konservasi lahan pada tingkat sedang. Model untuk meningkatkan pelaksanaan konservasi lahan yaitu meningkatkan: luas lahan, pemilikan ternak ruminansia, anggota keluarga yang bekerja, dan tingkat pendidikan, serta pemberdayaan untuk peningkatan partisipasi dalam konservasi lahan pada parameter yang masih rendah yaitu: penanaman tanaman penguat teras, penggunaan mulsa atau pupuk kandang, penanaman tanaman tahunan pada lahan miring, pergiliran tanaman, dan rasa tanggung jawab petani.
\end{abstract}

Kata kunci: model partisipasi, konservasi, usahatani tanaman pangan, lahan kering

\section{PENDAHULUAN}

Luas permukaan bumi yang potensial dipergunakan hanya sebesar 22 persen atau hanya 14.900 juta ha. Sesuai dengan semakin meningkatnya kebutuhan pangan penduduk maka penggunaan lahan pertanian meningkat (Morgan, 2005). Dewasa ini kepemilikan lahan ratarata per kapita penduduk dunia maupun di Indonesia semakin menurun (Suripin, 2004).
Tekanan penduduk atas lahan meluas ke semua pelosok pedesaan di tanah air, termasuk ke daerah-daerah lahan kering. Lahan kering sebagian besar berada di daerah aliran sungai (DAS). Suripin (2004), Arsyad (2006) menjelaskan bahwa DAS dibatasi oleh pemisah topografi, yang menerima air hujan, menampung, menyimpan dan mengalirkan ke sungai, seterusnya ke danau, dan atau ke laut. Rahim (2003), Leopold, Wolman, dan Miller (Suripin, 2004), 
dan Morgan (2005) menjelaskan bahwa melalui pendekatan aliran sungai dapat dijadikan basis pengelolaan lahan kritis. Mudah dipahami bahwa terjadinya erosi umumnya bisa diketahui melalui perubahan pola aliran sungai

Wilayah DAS semakin ke hulu semakin bergelombang dan berbukit sehingga kemiringan lahan semakin besar. Penggunaan lahan seharusnya dilaksanakan selaras dengan kemampuan lahan, pada lahan-lahan dengan kemiringan lebih dari 15 persen tidak dianjurkan untuk usahatani tanaman pangan, kecuali dengan syarat dibarengi dengan upaya-upaya konservasi lahan secara baik. Lahan pada DAS hulu dengan kemiringan yang tinggi mempunyai potensi erosi yang tinggi pula. Budidaya pertanian pada lahan dengan kemiringan tinggi jika dilaksanakan dengan tanpa memperhatikan prinsip-prinsip konservasi lahan maka lahan akan menjadi tidak subur, bahkan kritis, dengan produktivitas lahan rendah (Arsyad, 2006).

Para petani pada umumnya telah melakukan konservasi lahan walaupun dengan derajat yang berbeda. Sebagian petani pada lahan miring telah membuat teras bangku, namun belum sempurna, belum dilengkapi dengan tanaman penguat teras. Tanaman penguat teras dapat berupa rumput pakan ternak atau tanaman tahunan, tidak mudah diterima semua petani karena alasan persaingan tanaman utama yaitu tanaman padi, palawija, dan sayuran dengan tanaman penguat teras, atau karena petani tidak memiliki ternak ruminansia. Upaya konservasi lahan dengan pergiliran tanaman, pengolahan dan pembudidayaan tanaman sesuai garis contour juga tidak mudah diadopsi, karena keterbatasan pengetahuan dan keterampilan pada sebagian petani. Demikian pula dalam penggunaan pupuk mulsa dan pupuk kandang, sebagian petani tidak memiliki ternak ruminansia sebagai penghasil pupuk kandang.

Tingkat partisipasi petani dalam konservasi lahan dapat divaluasi melalui penerapan parameter-parameter pelaksanaan konservasi lahan yang dalam hal ini merujuk kepada Triastono (2006), didekati dengan konsep Indeks Kegiatan Konservasi (IKK). Tingkat IKK pada lahan kering bagi para petani dapat beragam, sesuai tingkat kesadaran petani, dan kondisi sosial ekonomi petani. Perlu dikaji berbagai paremeter IKK yang telah dilaksanakan secara baik oleh para petani atau parameterparameter yang yang belum dilaksanakan secara baik oleh para petani.

Pengembangan konsep IKK sebagai teknologi bersifat spesifik lokasi penting untuk dipergunakan memberdayakan para petani meningkatkan partisipasi para petani tanaman pangan lahan kering dalam konservasi lahan. Peningkatan partisipasi petani dalam konservasi lahan di wilayah Sub DAS Solo Hulu yang pada hilirnya bermuara pada Waduk Gajah Mungkur Wonogiri penting untuk mewujudkan usahatani yang berkelanjutan (lestari) serta mengurangi laju sedimentasi waduk.

Kawasan DAS merupakan ekosistem yang menyimpan sumberdaya alam seperti tanaman, tanah, dan air. Jika sumberdaya alam yang terkandung dalam suatu DAS tidak dikelola dan ditata dengan baik, maka dapat mengganggu keseimbangan lingkungan hidup seperti: (1) terganggunya keseimbangan tata air yang dicerminkan oleh fluktuasi debit maksimum dan minimum, (2) tingginya laju erosi dan sedimentasi, (3) merosotnya tingkat kesuburan lahan dan penurunan produktivitas lahan, (4) terjadinya bencana alam seperti banjir, tanah longsor, atau kekeringan, dan (5) terancamnya kelestarian terutama umur guna waduk atau bangunan air (Syehan dalam Triastono, 2006).

Para petani di kawasan DAS hulu, sebagaimana para petani yang jauh dari kota, pada umumnya dengan sarana dan prasarana perhubungan terbatas, sehingga para petani dapat lebih bertumpu pada usahatani. Para petani tersebut pada umumnya berusahatani tanaman pangan, yaitu padi, palawija, dan sayur-mayur. Merujuk kepada hasil penelitian Suwarto (2007), jika pemilikan atau penguasaan lahan usahatani sempit, walaupun lahan dengan kemiringan tinggi, lebih dari 15 persen para petani tersebut masih menggunakan untuk usahatani tanaman pangan. Kondisi demikian dapat menimbulkan erosi, penurunan kesuburan dan produktivitas lahan.

Tujuan penelitian ini dirumuskan: (1) sesuai konsep IKK penelitian ini mendiskripsikan 
tingkat partisipasi petani lahan kering dalam konservasi lahan, (2) menjelaskan faktor-faktor sosial ekonomi petani apa saja yang berpengaruh terhadap IKK oleh para petani, (3) mengembangkan model IKK spesifik lokasi yang sesuai untuk meningkatkan partisipasi petani dalam konservasi lahan.

Pengertian Lahan Kering. Lahan kering adalah sehamparan lahan yang tidak pernah tergenang atau digenangi air pada sebagian besar waktu dalam setahun atau dalam sepanjang tahun (Dariah, A., A. Rachman, dan U. Kurnia, 2004). Sebagaian besar lahan kering mendapatkan air dari hujan sehingga disebut lahan tadah hujan. Selari (Suwarto, 2010) menjelaskan bahwa lahan kering memiliki lapisan olah dan lapisan bawah dengan kadar air sepanjang tahun berada di bawah kapasitas lapang.

Selari (Suwarto, 2010) menjelaskan bahwa dewasa ini lahan kering memiliki arti yang semakin strategis karena berbagai pertimbangan seperti: (1) terus meningkatnya kebutuhan pangan dan hasil-hasil pertanian lainnya, (2) semakin terbatasnya lahan-lahan yang cocok untuk pembuatan sawah baru, mahalnya biaya pembuatan sawah pada setiap kesatuan luasnya, serta banyaknya konversi penggunaan sawah untuk keperluan pembangunan lainnya, (3) masih terus bertambahnya angkatan kerja baru yang terjun ke sektor pertanian karena terbatasnya kesempatan kerja pada luar sektor pertanian, dan (4) konsekuensi dari pembangunan itu sendiri. Sejalan dengan itu, Hidayat dan Mulyani dalam Dariah, A. et al., (2004) dan M. K. McLeod dan Rahmianna (2009) mengemukakan bahwa lahan kering merupakan sumberdaya lahan yang memiliki potensi besar untuk menunjang pembangunan pertanian di Indonesia. Lahan kering di Indonesia meliputi luasan lebih dari 140 juta ha (Hidayat dan Mulyani dalam Dariah et al, 2004), kurang lebih 56 juta ha di antaranya (di luar Maluku dan Papua) sudah dipergunakan untuk pertanian (BPS, 2001).

Sebagai salah satu faktor produksi dalam budidaya pertanian yang berasal dari alam, lahan kering mempunyai sifat yang unik dan penting. Lahan adalah sumberdaya alam yang bersifat irreplaceable. Konke dan Bertrand (Suwarto, 2010), menekankan bahwa apabila lahan (top soil) telah hilang, terendap di dasar sungai, dan dasar laut maka dikatakan tidak mungkin dikembalikan lagi dengan pengetahuan dan teknologi yang kita miliki sekarang ini. Apabila tanah subur telah hilang maka diperlukan waktu bertahun-tahun atau bahkan ratusan tahun untuk mengembalikan tanah menjadi subur kembali. Sejalan dengan hal tersebut Santoso, D.J. et al., (2004) dan Daiah, A. et al., (McLeod dan Rahmianna (2009) menjelasdkan bahwa usahatani tanaman pangan secara intensif dan menetap pada lahan kering di daerah hujan tropis dihadapkan pada masalah penurunan produktivitas lahan. Salah satu penyebabnya adalah tanahnya peka terhadap erosi, berlereng, bereaksi asam, dan miskin unsur hara. Oleh karena itu untuk mencapai usahatani keberlanjutan maka usahatani harus menerapkan konservasi lahan.

Erosi Lahan. Morgan (2005) dan Arsyad (2006) mendefinisikan erosi sebagai suatu proses pelepasan dan pengangkutan tanah atau bagian-bagian tanah dari suatu tempat ke tempat lain oleh penyebab erosi. Menurut penyebabnya atau media pengangkutannya, para ahli membedakan dua jenis erosi yaitu erosi air dan erosi angin. Lebih lanjut dijelaskan oleh Morgan (2005), dan Arsyad (2006) bahwa untuk daerah beriklim basah seperti Indonesia, erosi airlah yang menyebabkan kerugian yang besar.

Erosi lahan dan penurunan kesuburan lahan menjadi masalah utama di pegunugan $\mathrm{Ne}-$ pal, dan di wilayah lainnya yang memiliki implikasi serius pada ketahanan pangan dan kehidupan masyarakat lokal (Keathing et al, 1999 dan Shestha et al, 2004) dalam Tiwari et.al., 2008).

Laju erosi tanah yang cepat terjadi pada sebagian besar daerah pertanian di seluruh dunia, dan dapat menyebabkan tanah menjadi marjinal. Dalam hal ini Pimmentel (Suripin, 2004) mengemukakan bahwa rata-rata perkiraan kehilangan tanah terkecil di Eropa berkisar antara 10-20 ton ha-1 tahun ${ }^{-1}$, lahan pertanian di Amerika Serikat kehilangan lebih kurang 16 ton ha $^{-1}$ tahun $^{-1}$, dan Afrika, Amerika Selatan, dan Asia kehilangan tanah mencapai 20-40 ton ha-1 
tahun $^{-1}$. Pande , V.C. et al., (2011) menjelaskan bahwa permasalahan degradasi lahan dan erosi telah menarik perhatian pengambil kebijakan sejak lama. Rata-rata tahunan kehilangan $n \mathcal{n}$ trient dari lahan karena erosi ditaksir sebesar 5,37-8,4 juta ton.

Di samping menurunkan kesuburan tanah, erosi tanah menyebabkan problem lingkungan di daerah hilir suatu DAS. Sedimen hasil erosi mengendap dan mendangkalkan sungai-sungai, waduk, dan danau sehingga mengurangi kemampuan sumberdaya tersebut untuk irigasi, pembangkit listrik, perikanan, navigasi, dan rekreasi (Suripin, 2004). Dalam hal ini sedimentasi di waduk Gajah Mungkur sebagai hilir dari sub DAS Solo Hulu, wilayah penelitian sudah mencapai tingkat yang mengkhawatirkan (Mukhlisin, M, 2007, Darmawan, A., 2009).

Faktor-faktor yang Mempengaruhi Erosi. Suripin (2004) dan Arsyad (2006) menjelaskan bahwa faktor-faktor yang mempengaruhi erosi lahan yaitu iklim, topografi, vegetasi, dan tindakan campur tangan manusia.

(1) Iklim. Faktor iklim yang mempengaruhi erosi adalah hujan, besarnya curah hujan, intensitas, dan distribusi hujan sepanjang tahun menentukan kekuatan dispersi hujan atas lahan pertanian, jumlah dan kekuatan aliran permukaan serta tingkat kerusakan erosi yang terjadi (Arsyad (2006). Jika lahan dalam keadaan kering dan intensitas air hujan tinggi, maka agregat tanah akan pecah dengan cepat, infiltrasi tanah cepat berkurang permukaan tanah menjadi licin dan aliran permukaan dapat ditentukan walaupun curah hujan hanya beberapa mm saja (Morgan, 2005). Angin adalah faktor lain yang menentukan kecepatan jatuhnya butir hujan, dalam hal ini kecepatan maksimum jatuhnya butir hujan adalah $33 \mathrm{~km} \mathrm{jam}^{-1}$. Angin yang berkecepatan lebih besar, kencang dapat memperbesar kecepatan jatuhnya butir hujan sehingga dapat memperparah erosi (Arsyad, 2006)

(2) Topografi. Kemiringan dan panjang lereng adalah dua kondisi yang paling berpengaruh terhadap aliran permukaan dan erosi. Kemiringan lereng dinyatakan dalam derajat atau persen. Dua titik yang berjarak $100 \mathrm{~m}$ yang mempunyai selisih setinggi $10 \mathrm{~m}$ membentuk lereng 10 persen (Arsyad, 2006). Semakin besar kemiringan dan semakin panjang lereng, maka tingkat erosi akan semakin besar. Pada lahan yang miring terpaan air hujan menyebabkan lebih banyak melemparkan partikel tanah ke udara arah bagian rendah. Selanjutnya semakin panjang lereng cenderung semakin banyak air permukaan yang terakumulasi, sehingga aliran permukaan menjadi lebih dalam dan tinggi kecepatannya (Baver dalam Suripin, 2004).

(3) Vegetasi. Vegetasi berfungsi sebagai pelindung atau penyangga antara atmosfir dan tanah atau lahan Morgan (2005) dan Arsyad (2006). Suatu vegetasi yang baik seperti pada rimba yang lebat atau rumput yang tebal dapat menghilangkan pengaruh hujan dan topograsi terhadap erosi. Bagian vegetasi yang berada di permukaan tanah seperti daun, ranting, dan batang menyerap energi perusak hujan, sedangkan bagian vegetasi yang berada di dalam tanah, yang terdiri atas sistem perakaran meningkatkan kekuatan mekanik tanah. Pengaruh vegetasi terhadap aliran permukaan dan erosi meliputi: (1) intersepsi air hujan, (2) mengurangi kecepatan aliran permukaan, dan kekuatan perusak hujan, dan (3) pengaruh akar, bahan organik (Arsyad, 2006)

(4) Tanah. Berbagai jenis tanah atau lahan pertanian mempunyai kepekaan yang berbeda terhadap erosi (Arsyad, 2006), dalam hal ini Bastos, G.S. and E. Lichtenberg (2001) Dariah, A., et al., (2004b), dan Morgan (2005) menyebutnya sebagai erodibilitas tanah. Lebih jauh Morgan (2005) dan Arsyad (2006) menjelaskan bahwa sifat-sifat fisik dan kimia tanah yang mempengaruhi erosi yaitu: (a) sifat-sifat tanah yang mempengaruhi infiltrasi, permeabilitas dan kapasitas menahan air, dan (b) sifat-sifat tanah yang mempengaruhi ketahanan struktur tanah terhadap dispersi dan penghancuran agregat tanah oleh tumbukan butir-butir hujan dan aliran permukaan.

Di negara-negara tropis seperti Indonesia, kekuatan jatuhnya air hujan dan kemampuaan aliran permukaan menggerus permukaan tanah menentukan besarnya erosi tanah (Dariah, A. et al., (2004b). Dalam hal ini Rachman et al., (Dariah, A. et al., (2004b) pengelolaan lahan pertanian yang mengakumulasi sisa-sisa tanaman berpengaruh baik terhadap kualitas lahan, yai- 
tu terjadinya stabilitas agregat tanah, ketahanan tanah (shear strengh), dan resistensi tanah terhadap daya hancur terpaan air hujan (splash detachment)

Konservasi Lahan. Konservasi lahan bertujuan mendapatkan tingkat keberlanjutan produktivitas lahan dengan menjaga kehilangan lapisan olah lahan di bawah ambang batas yang diperkenankan (Suripin, 2004). Sejalan dengan itu, Morgan (2005) mengemukakan bahwa konservasi lahan adalah upaya mengurangi kehilangan lahan sehingga erosi yang terjadi sebagaimana peristiwa secara alami, melalui berbagai strategi termasuk memahami proses erosi. Arsyad (2006) menjelaskan bahwa konservasi lahan sebagai pengawetan lahan yang dimaksudkan sebagai penempatan sebidang tanah pada cara penggunaan yang sesuai dengan kemampuan tanah tersebut dan memperlakukannya sesuai dengan syarat-syarat yang diperlukan agar tidak terjadi kerusakan tanah. Sejalan dengan itu DSCW (2004) dan Hudson (1991) dalam Tiwari, K.R., et al., (2008) mendifinisikan konservasi lahan sebagai penggunaan sumberdaya lahan secara rasional, menerapkan pengendalian terhadap erosi, menggunakan pola pertanaman yang tepat untuk meningkatkan produktivitas lahan dan mencegah degradasi lahan.

Kohnke dan Betrand (Suwarto, 2010) mengungkapkan bahwa konservasi tanah adalah penggunaan tanah secara bijaksana, terutama dengan mematuhi pengendalian erosi. Sejalan dengan itu, Arsyad (2006) mengungkapkan bahwa tiap kelas penggunaan tanah memerlukan teknik tertentu. Pande, V.C. et al., (2011) mengemukakan bahwa konservasi lahan pertanian sebagai obat atas permasalahan suatu wilayah pertanian.

Selanjutnya secara sistematis Suripin (2004), Dariah, A. et al. (2004), dan Arsyad (2006) menjelaskan bahwa metode konservasi lahan secara garis besar meliputi: (1) metode vegetatif, (2) metode mekanis dan (3) metode kimia.

(1) Metode Vegetatif. Metode vegetatif dalam konservasi lahan pada dasarnya ditujukan untuk: (a) melindungi tanah terhadap daya perusak butir-butir hujan yang jatuh, (b) melindungi tanah terhadap daya perusak aliran air di atas permukaan tanah, dan (c) memperbaiki kapasitas infiltrasi tanah dan absorpsi air yang langsung akan menurunkan jumlah aliran permukaan serta mempengaruhi waktu tercapainya puncak aliran permukaan.

Cara-cara yang umum dan banyak dilakukan yang termasuk dalam metode vegetasi menurut Suripin (2004) yaitu: (a) permanen plant cover, (b) strip cropping, (c) cropping rotation, (d) residu management, dan (e) multiple cropping. Di samping itu dijelaskan oleh Suripin (2004) dan Arsyad (2006), bahwa penghutanan atau penghijauan dan penanaman dengan tanaman penutup tanah secara permanen juga termasuk upaya konservasi lahan dalam klsasifikasi metode vegetatif.

(2) Metode Mekanik. Pada dasarnya metode mekanik dalam konservasi tanah dan air ditujukan untuk: (a) memperlambat kecepatan aliran permukaan dan (b) menampung dan mengalirkan air permukaan dengan kekuatan yang tidak merusak. Cara-cara konservasi lahan yang termasuk dalam metode mekanik, yaitu: (a) tillage, (b) contour ridges and furrows), (d) terraces), (e) water ways), dan (f) water retardance structures, form pound, rorak, tanggul, dan sebagainya (Arsyad, 2006). Sejalan dengan itu, Suripin (2004) menjelaskan bahwa usaha-usaha yang dapat dilakukan dalam budidaya pertanian berwawasan konservasi lahan yaitu: (a) lahan diolah seperlunya saja, (b) pengolahan lahan dilakukan sejajar garis contour, (c) pengolahan lahan sebaiknya diikuti pemberian mulsa, jadi dalam hal ini dapat dipraktekkan beberapa macam metode konservasi secara simultan.

(3) Metode Kimia.Struktur tanah merupakan merupakan salah satu sifat tanah yang menentukan kepekaan tanah tyerhadap erosi. Oleh karena itu sejak tahun 1950an telah dimulainya usaha-usaha untuk memperbaiki struktur tanah melalui pemberian preparat-preparat kimia yang secara umum disebut pemantap tanah atau soil conditioner (Suripin, 2005, dan Arsyad, 2006). Metode ini untuk di Indonesia dan negara berkembang lainnya jarang dipergunakan karena mahal. Arsyad (2006) mengemukakan bahwa untuk memantapkan struktur tanah dapat dipergunakan pemberian bahan organik. Bahan organik tanah berperan sebagai 
reservoir unsur hara, memperbaiki struktur tanah, drainase tanah, peredaran udara tanah, kapasitas tukar kation, kapasitas penyangga tanah, kapasitas penahan air, dan sumber energi bagi mikro organisme tanah.

IKK sebagai Parameter Partisipasi Masyarakat Tani pada Konservasi Lahan. Sejalan dengan kaidah-kaidah konservasi lahan, dan dengan merujuk kepada Pakpahan (1992), Suwarto, (1995), Triastono (2006) maka valuasi partisipasi petani dalam konservasi lahan dapat didekati dengan Indeks Kegiatan Konservasi Lahan (IKK) meliputi: (1) pembuatan teras/ galengan pada lahan miring, (2) penanaman tanaman atau rumput penguat teras, (3) pengolahan lahan sesuai garis contour, (4) pembudidayaan tanaman sesuai garis contour (5) pergiliran tanaman semusim, (6) penanaman tanaman tahunan pada lahan yang kemiringannya tinggi, (7) penggunaan mulsa atau pupuk kandang, (8) pemeliharaan teras atau galengan, (9) pembuatan saluran drainase, dan (10) rasa tanggung jawab petani atas konservasi lahan.

Pelaksanaan kegiatan konservasi lahan para petani dapat bervariasi, sebagaimana yang terjadi di wilayah pertanian pada umumnya. Menurut Brown dan Shrestha (2000), Paudel dan Thapa (2004) dalam Tiwari et al. (2008) di samping ketersediaan berbagai teknologi konservasi yang dapat dipilih dan diterapkan dalam konservasi lahan, tingkat adopsi konservasi rendah dan penurunan kesuburan lahan terus berlangsung di wilayah pegunungan Nepal. Sementara itu, berbagai pihak juga mengakui bahwa penghargaan atas lahan sebenarnya telah berlangsung lama, karena lahan adalah faktor produksi yang penting dalam pertanian (Suripin, 2004). Chouinard, H.H., et al., (2008) menjelaskan bahwa motif petani melakukan konservasi lahan dapat beragam yaitu motif ekonomi, supaya produktivitas lahan dan pendapatan usahatani meningkat atau alasan sosial, sudah seharusnya para petani menjaga lahan supaya tetap subur, karena lahan pertanian juga milik generasi mendatang, atau karena rasa terima kasih kepada Tuhan yang harus dilakukannya.

Pembuatan teras pada lahan miring menurut hasil-hasil penelitian pada umumnya telah dilaksanakan oleh para petani. Namun pada umumnya pembuatan teras tersebut tidak sempurna, seperti belum dilengkapi dengan tanaman penguat teras (Triastono, 2006, Suwarto, 2007). Tanaman penguata teras sangat penting dalam konservasi lahan. Kegiatan penanaman tanaman atau rumput penguat teras banyak dilakukan oleh para petani yang memelihara ternak ruminansia, karena tanaman tersebut sangat potensial menjadi sumber pakan ternak bagai para peetani (Suwarto, 2007). Sebagian petani enggan menanam rumput atau tanaman lain untuk penguat teras karena mengurangi luas lahan yang ditanami tanaman pangan (Dariah, A. et al. 1989) dalam Suwarto, 2010).

Pengolahan lahan sesuai garis contour telah diterapkan oleh para petani, misalnya para petani yang membajak lahan pada lahan yang telah dibuat teras. Walaupun demikian, sebagian petani belum melakukannya. Pembudidayaan tanaman sesuai garis contour dimaksudkan supaya barisan-barisan tanaman dapat memotong aliran permukaan air hujan sehingga dapat menekan laju erosi lahan (Arsyad, 2006, dan Suripin, 2004). Para petani yang lahannya sudah dibuat teras pada umumnya melakukan hal tersebut, yaitu terutama untuk tanaman semusim yang agak tinggi seperti jagung dan ubi kayu (Suwarto, 2007).

Para petani lahan kering di Pulau Jawa pada umumnya melakukan pergiliran tanaman semusim sesuai pola tanam, padi pada musim tanam pertama dan palawija pada musim tanam ke dua. Arsyad (2006) menjelaskan bahwa pergiliran tanaman yang terbaik sesuai kaidah konservasi lahan yaitu yang di antaranya menggunakan tanaman leguminosa, yaitu tanaman yang dapat mengikat nitrogen $(\mathrm{N})$ bebas dari udara. Lebih jauh Arsyad (2006) menjelaskan bahwa di samping berguna dalam pencegahan erosi, melalui pergiliran tanaman dapat diperoleh keuntungan-keuntungan lain seperti: (1) mengendalikan hama dan penyakit karena dapat memutus siklus hidup hama dan penyakit, (2) memberantas gulma, penanaman satu jenis tanaman tertentu trus-menerus akan meningkatkan pertumbuhan gulma jenis tertentu, (3) mempertahankan dan memperbaiki sifat fisik tanah, dan (4) memelihara keseimbangan unsur hara dalam tanah, karena absorpsi unsur 
dari kedalaman dan freferensi yang berbeda.

Penanaman tanaman tahunan pada lahan yang kemiringannya tinggi penting dilakukan dalam konservasi lahan menggunakan metode vegetatif, karena upaya tersebut dapat menekan laju erosi, atau dapat ditujukan untuk mencegah tanah longsor. Hasil penelitian Triastono (2006) di kabupaten Boyolali mendapatkan lebih $90 \%$ para petani menanam tanaman keras pada lahan yang miring. Penggunaan mulsa atau pupuk kandang dapat memperbaiki sifat fisik lahan dan menambah kesuburan lahan, aktivitas tersebut termasuk konservasi lahan menggunakan metode vegetatif (Arsyad, 2006) dan Suripin, 2004).

Pemeliharaan teras atau galengan yaitu aktivitas memelihara bangunan teras atau galengan yang biasanya mengalami kerusakan akibat aliran permukaan air hujan. Aktivitas tersebut termasuk konservasi lahan menggunakan metode mekanik (Arsyad, 2006, Suripin, 2004, dan Rahim, 2003). Para petani di kabupaten Gunung Kidul melakukan pemeliharaan teras atau galengan dilakukan baik pada musim penghujan maupun pada musim kemarau (Suwarto, 2007). Pembuatan saluran drainase dilakukan para petani supaya aerase tanah baik, terutama ditujukan untuk tanaman palawija. Pembuatan dan pemeliharaan saluran drainase tersebut termasuk konservasi lahan menggunakan metode mekanik (Arsyad, 2006, Suripin, 2004, dan Rahim, 2003).

Suwarto (1995) memasukkan parameter rasa tanggung jawab petani dalam meneliti persepsi petani terhadap konservasi lahan. Suatu hal yang mengurangi rasa tanggung jawab petani atas konsevasi lahan yaitu masih terus diharapkannya oleh sebagian petani adanya bantuan pemerintah dalam pelaksanaan konservasi lahan.

Faktor-faktor yang Mempengaruhi Petani Melaksanakan Konservasi Lahan. Menurut Lynch, L. dan W.N. Musser (2001), masalah ketahanan pangan, kondisi ekonomi masyarakat setempat, dan nilai ketenteraman menimbulkan kebutuhan untuk nenentukan kebijakan dan penelitian dalam pengamanan lahan pertanian. Lebih jauh Gardner (Lynch, et al., 2001) mengemukakan empat keuntungan yang dapat diperoleh dari menjaga produktivitas lahan pertanian yaitu: (1) keamanan pangan tingkat lokal maupun nasional, (2) penyerapan tenaga kerja pada agro industri, (3) penggunaan lahan pedesaan maupun wilayah urban secara efisien, dan (4) perlindungan atau penjagaan keamanan lingkungan dan pedesaan. Dalam hal ini Chouinard, et.al., (2008) mengemukakan bahwa Pemerintah Amerika Serikat berperan aktif dalam melaksanakan program konservasi lahan. Dilaporkan bahwa anggaran untuk pertanian Pemerintah Amerika Serikat sejak tahun 2002 mencapai lebih dari \$ 38 milyar untuk program konservasi. Kerjasama pembiayaan atau shering pembiayaan dalam program konservasi lahan tersebut dilakukan antara pemerintah dengan pemilik lahan pertanian.

Para petani mengelola lahan yang berbeda dengan lahan yang dikelola petani lain dalam tingkat produktivitas, dan ketahanan terhadap erosi, sehingga pilihan terhadap jenis konservasi lahan juga berbeda (Lichtenberg, E., and R. Smitth-Ramirez, (2010). Sejalan dengan itu, partisipasi para petani dalam konservasi lahan dapat berbeda antarwilayah, sesuai jenis lahan, luas lahan, ketersediaan off farm dan non farm, dan keberadaan program pemerintah (Chang, H., and R.N. Boisvert, 2009). Ketersediaan off dan non farm menurunkan partisipasi dalam konsercvasi lahan di Amerika Serikat, karena para petani mengurangi waktu berkeja pada sektor pertanian (Chang, H., and R.N. Boisvert, 2009). Hasil penelitian ini berbeda dengan hasil penelitian Suwarto (2007) pada lahan kering di kabupaten Gunung Kidul, dengan kondisi tekanan penduduk atas lahan sedemikian tinggi, ketika lapangan pekerjaan off farm dan non farm sulit diakses maka tekanan penduduk atas lahan semakin tinggi, hingga penduduk membudidayakan tanaman pangan sampai pada punggung-punggung bukit berbatu yang tandus.

Partisipasi petani secara parsial meningkat dengan tingginya luas lahan yang dimiliki. Banyak pihak yang seperti Tiwari, K.R. at al. (2008), Asafu-Adjaye, J. ( 2008), Chang, H. et al., (2009), Lichtenberg, E. et al., (2010), dan Pande, V.C. et al., (2011), melaporkan bahwa luas lahan usahatani menyebabkan meningkatnya partisipasi petani dalam konservasi lahan. Hal ini 
dapat sejalan motivasi para petani melaksanakan konservasi lahan. Para petani yang berlahan luas dapat mewakili kelompok petani yang melaksanakan konservasi lahan karena merasa lahan yang dikelolanya adalah juga milik generasi mendatang sehingga harus dijaga kesuburannya, dan hal ini juga merupakan pengabdian kepada Tuhan (Wallace dan Clesrfield dalam Chouinard, et al., 2008). Dalam hal ini AsafuAdjaye, J. ( 2008) menjelaskan bahwa pelaksanaan konservasi lahan dimulai dari persepsi para petani dalam konservasi lahan. Hasil penelitiannya mendapatkan faktor-faktor yang mempengaruhi persepsi para petani terhadap konservasi lahan yaitu umur, pendidikan, etnik, dan jasa penyuluhan. Dalam hal ini faktorfaktor yang mempengaruhi pelaksanaan konservasi lahan yaitu: keuntungan usahatani, luas lahan, jenis lahan, dan jasa penyuluhan. Karakteristik personal mempengaruhi persepsi, sedangkan pelaksanaan konservasi dipengaruhi oleh faktor fisik dan ekonomi.

Tiwari, K.R. et al., (2008), dalam penelitiannya mengeksplorasi perbedaan faktor sosial ekonomi dan institusi berpengaruh terhadap adopsi peningkatan teknologi konservasi lahan. Melalui model logistik regresi, memprediksi tujuh faktor yang mempengaruhi tingkat adopsi yaitu meliputi: pendidikan kepala keluarga, kasta, luas penguasaan lahan, jenis tanaman sayuran, pekerjaan angota keluarga pada off farm, keanggotaan dalam kelompok pengembangan konservasi, dan penggunaan kredit.

Dalam hal ini Holden, S.T. et al., 2009 menjelaskan bahwa hak kepemilikan lahan dapat meningkatkan partisipasi para petani dalam konservasi lahan. Pengakuan hak kepemilikan lahan (sertifikat) bukti yang bermanfaat unuk mendapatkan keamanan kepemilikan, serta sertifikat kepemilikan dapat dipergunakan untuk mengakses kredit, atau peningkatan nilai lahan. Biaya yang murah dalam pengurusan sertifikat yang diterapkan di Ethiopia pada akhir 1990an berkontribusi meningkatkan keamanan kepemilikan lahan dan menurunkan perselisihan kepemilikan lahan. Keamanan kepemilikan lahan telah meningkatkan investasi atas lahan, seperti penanaman tanaman tahunan, perbaikan manajemen konservasi lahan dan mening- katkan produktivitas lahan. Juga sertifikasi lahan dapat meningkatkan penggunaan input produksi seperti pupuk organik, dan anorganik, dan penggunaan input lainnya.

Bukti pentingnya pelaksanaan konservasi lahan di antaranya dicermati dengan adanya kerja sama pembiayaan dalam pelaksanaan konservasi lahan antara pemerintah dengan para petani pemilik lahan. Menurut Lichtenberg, E. et al., (2010) faktor-faktor yang dapat berpengaruh terhadap keikutsertaan para petani dalam program kerja sama pembiayaan konservasi lahan yaitu: umur petani, pendidikan formal petani, luas penguasaan lahan, dan jumlah ternak ruminansia yang dipelihara petani. Dalam hal ini Bastos, G.s. et al., (2001) mengemukakan bahwa kegiatan konservasi lahan yang menjanjikan akan meningkatkan produksi dan pendapatan para petani sepertinya mendapatkan kerjasama dalam pendanaan yang lebih besar

Konservasi lahan adalah kegiatan pemeliharaan lahan pertanian yang bersifat investasi, yang dalam hal ini hasilnya tidak langsung bisa dilihat dalam meningkatkan produksi pertanian pada jangka pendek. Sejalan dengan itu dikemukakan oleh Pande, V.C. et al., (2011) bahwa faktor-faktor yang mempengaruhi petani mengambil keputusan untuk berinvestasi, melakukan konservasi lahan yaitu luas penguasaan lahan pertanian, cas crop, dan tersedianya kredit untuk melakukan konservasi. Luas penguasaan lahan, pendapatan dari cas crop, tersedianya serta kredit jangka panjang yang lunak mencerminkan kemudahan bagi para petani untuk berinvestasi melakukan konservasi lahan.

Mengenai faktor-faktor penyebab kritisnya lahan di DAS bagian hulu yaitu selain karena kondisi lingkungan fisik dan iklim setempat yang mendukung terjadinya percepatan erosi diakibatkan pula oleh cara pengelolaan lahan yang kurang sesuai dengan kaidah-kaidah konservasi. Hal ini disebabkan oleh kondisi pengetahuan dan sosial ekonomi petani di lahan kering kurang mendukung terciptanya penggunaan lahan secara lestari (Nasution, 2004).

Sub DAS Solo Hulu. DAS Bengawan Solo meliputi tiga Sub DAS yaitu Sub DAS Solo 
Hulu, Sub DAS Solo Hilir, dan Sub DAS Kali Madiun (Darmawan, 2009). Sub DAS Solo hulu berada pada lahan atas dari Waduk Gadjah Mungkur kabupaten Wonogiri, merupakan daerah didominasi lereng yang curam, dalam hal ini kawasan DAS Solo Hulu termasauk kawasan kritis, berada di kabupaten Wonogiri (Pramono, BI., et al, 2010).

Kabupaten Wonogiri meliputi sekitar 182.232 ha, dengan penutupan lahan yang dominan adalah tegal (35,88 persen), diikuti oleh pekarangan $(20,96$ persen), sawah $(17,94$ persen), hutan Negara 7,65 persen, hutan rakyat 5,09 persen, dan sisanya merupakan penutupan lahan lain-lain (12,48 persen) (Wonogiri Dalam Angka, 2007). Jika dilihat dari topografinya, maka sebagian besar (65 persen) daerah Wonogiri berbentuk perbukitan dengan lereng yang terjal, areal landai (30 persen) dan hanya 5 persen merupakan areal datar. Kepemilikan lahan oleh penduduk adalah hak milik sehingga lahan dimanfaatkan untuk tanaman semusim, akibatnya tingkat erosi tinggi, kesuburan lahan rendah, banjir dan pendangkalan waduk Gajah Mungkur tidak terelakkan (Pramono,B.I. et al., 2010). Dalam hal ini sebagai suatu sistem, akibat terjadinya erosi yang tinggi di wilayah DAS Solo Hulu maka sedimentasi pada Waduk Gajah Mungkur berlangsung cepat (Darwawan, 2009, dan Mukhlisin, 2007). Sedimentasi waduk Gajah Mungkur dari Sub DAS Solo Hulu ratarata 3.180.000 $\mathrm{m}^{3}$ tahun $^{-1}$ (Mukhlisin, 2007).

Pemerintah Indonesia sebenarnya telah melakukan upaya menekan laju erosi di wilayah DAS Solo Hulu. Pemerintah Indonesia dengan bantuan Bank Dunia melakukan manajemen DAS Solo Hulu melalui "The Upper Solo (Wonogiri) Watershed Protection Project" di bawah Loan Agrreement No. 2930 IND yang ditanda tangani pada tanggal 20 April 1988 (Suripin, 2004). Walaupun demikian, mengingat masih tingginya tingkat erosi di wilayah Sub DAS Solo Hulu yang sebagian besar berupa lahan kering dengan kemiringan yang tinggi, maka konservasi lahan di wilayah tersebut harus ditingkatkan pelaksanaannya.

\section{METODE PENELITIAN}

Penelitian dilaksanakan di Dusun Pundung, Desa Kudi, Kecamatan Batuwarno Kabupaten Wonogiri yaitu wilayah pertanian yang berada di DAS Solo Hulu, yang pada hilirnya bernuara pada waduk Gajah Mungkur Wonogiri. Sebanyak $73 \mathrm{KK}$ penduduk di wilayah Sub DAS Solo Hulu, di Dusun Pundung, dua KK petani di antaranya menanami semua lahannya yang miring dengan tanaman jati, tidak dijadikan responden, demikian juga tiga KK petani tak berlahan, sebagai buruh tani tidak dijadikan responden. Dua KK petani yang menanami lahan usahataninya dengan kayu jati, dalam hal ini para petani tersebut dianggap telah melakukan konservasi lahan secara benar. Warga tersebut mendapatkan lapangan pekerjaan pada non farm sebagai mata pencaharian yang utama. Responden meliputi 68 KK dari semua Kepala Keluarga tani tanaman pangan pada lahan kering di wilayah penelitian.

Data yang dipergunakan dalam penelitian ini terutama data primer, yaitu data aktivitas konservasi lahan, meliputi semua aspek kegiatan konservasi lahan, sesuai dengan pengukuran IKK. Di samping itu juga data profil atau karakteristik petani yang harus dicatat meliputi umur, pendidikan formal, jumlah anggota keluarga, jumlah anggota keluarga yang bekerja, dan luas penguasaan lahan.

Pengumpulan data primer dengan survai (Singarimbun, 1989). Informasi mengenai data primer juga diperkuat dengan melakukan wawancara kepada tokoh-tokoh masyarakat dan petani dengan maksud untuk memperoleh informasi lebih lanjut, yang mampu menjelaskan suatu gejala yang tidak terekam oleh kuesioner yang disusun.

\section{Metode Analisis Data}

Tingkat Partisipasi Petani pada Konservasi Lahan. Valuasi tingkat partisipasi petani dalam konservasi lahan sesuai model IKK meliputi: (1) pembuatan teras/galengan pada lahan miring, (2) penanaman tanaman atau rumput penguat teras, (3) pengolahan lahan sesuai garis contour, (4) pembudidayaan tanaman sesuai garis contour (5) pergiliran tanaman semusim, (6) pena- 
naman tanaman tahunan pada lahan yang kemiringannya tinggi, (7) penggunaan mulsa atau pupuk kandang, (8) pemeliharaan teras atau galengan, (9) pembuatan saluran drainase, dan (10) rasa tanggung jawab petani atas konservasi lahan. Setiap item diberi penilaian sesuai besarnya partisipasi para petani dalam konservasi lahan. Penilaian partisipasi para petani dalam konservasi lahan tersebut merujuk kepada Suwarto (2010) diberikan dalam persentase ( 1 persen sampai dengan 100 persen). Besarnya penilaian yang diperoleh dari jawaban petani merupakan tingkat IKK yang mencerminkan upaya atau partisipasi para petani dalam konservasi lahan. Khusus untuk rasa tanggung jawab petani dalam konservasi lahan diukur dalam Skala Likert, yang selanjutnya dikonversikan ke dalam penilaian persentase. Penggolongan IKK selanjutnya dibagi dalam empat katagori sebagai berikut: IKK sangat rendah, nilai partisipasi petani dalam konservasi lahan 1,00 persen sampai dengan 25,00 persen, IKK rendah, nilai partisipasi petani dalam konservasi lahan 26,00 persen sampai dengan 50,00 persen, IKK sedang, nilai partisipasi petani dalam konservasi lahan 51,00 persen sampai dengan 75,00 persen, IKK tinggi, nilai partisipasi petani dalam konservasi lahan 76,00 persen sampai dengan 100,00 persen.

Selanjutnya Tingkat partisipasi yang dapat dicapai petani dalam melaksanakan konservasi lahan sesuai konsep IKK secara matematik dapat dirumuskan:

$\mathrm{IKK}_{1}=\mathrm{f}\left(\mathrm{X}_{\mathrm{i}}\right)$

dimana $i=1$ sampai dengan 10

Keterangan: IKK adalah Indeks Kegiatan Konservasi, $X_{1}$ adalah pembuatan teras/galengan pada lahan miring, $X_{2}$ adalah penanaman tanaman atau rumput penguat teras, $X_{3}$ adalah pengolahan lahan sesuai garis contour, $\mathrm{X}_{4}$ adalah pembudidayaan tanaman sesuai garis contour, $\mathrm{X}_{5}$ adalah pergiliran tanaman semusim, $\mathrm{X}_{6}$ adalah penanaman tanaman tahunan pada lahan yang kemiringannya tinggi, $X_{7}$ adalah penggunaan mulsa atau pupuk kandang, $X_{8}$ adalah pemeliharaan teras atau galengan, $X_{9}$ adalah pembuatan saluran drainase, dan $X_{10}$ adalah rasa tanggung jawab petani atas konservasi lahan

Tingkat partisipasi petani dalam konservasi lahan sesuai konsep IKK yang senyatanya dilaksanakan oleh para petani yang mencapai kriteria rendah atau tidak baik menurut hasil penelitian secara matematik dapat dirumuskan:

$\mathrm{IKK}_{1}{ }^{\prime}=\mathrm{f}\left(\mathrm{X}_{\mathrm{i}}{ }^{\prime}\right)$

$\mathrm{i}=1$ sampai dengan $\leq 10$

Faktor-faktor yang Mempengaruhi Partisipasi Petani Lahan Kering dalam Konservasi Lahan, IKK Masyarakat Tani di Sub DAS

Tingkat partisipasi para petani dalam konservasi lahan sesuai model IKK dapat dijelaskan dengan model regresi berganda sebagai berikut:

$\mathrm{IKK}_{2}=\alpha+\beta_{1} \mathrm{Y}_{1}+\beta_{2} \mathrm{Y}_{2}+\beta_{3} \mathrm{Y}_{3}+\beta_{4} \mathrm{Y}_{4}+$

$$
\beta_{5} \mathrm{Y}_{5}+\beta_{6} \mathrm{Y}_{6}+\mu
$$

Keterangan: $\mathrm{IKK}_{2}$ adalah indek kegiatan konservasi (\%), $\alpha$ adalah intersep, $\beta_{i}$ adalah koefisien regresi ( $i=1$ sampai dengan 6 ), $Y_{1}$ adalah luas penguasaan lahan (ha), $Y_{2}$ adalah ternak ruminansia (ekor, standar sapi), $Y_{3}$ adalah jumlah anggota rumah tangga (jiwa), $\mathrm{Y}_{4}$ adalah jumlah anggota rumah tangga yang bekerja (orang), $\mathrm{Y}_{5}$ adalah umur Kepala Keluarga (tahun), $\mathrm{Y}_{6}$ adalah pendidikan formal Kepala keluarga petani (tahun), $\mu$ adalah error term.

Faktor-faktor yang berpengaruh nyata terhadap IKK menurut hasil penelitian, sesuai hasil analisis regresi berganda model 3 secara matematik dapat dirumuskan:

$\mathrm{IKK}_{2}^{\prime}=\mathrm{f}\left(\mathrm{Y}_{\mathrm{i}}^{\prime}\right)$

$Y_{i}^{\prime}=i=1$ sampai dengan $\leq 6$

Keterangan: IKKL ${ }_{2}^{\prime}$ adalah indeks kegiatan konservasi (\%), $\mathrm{Y}_{1}$ adalah luas penguasaan lahan (ha), $Y_{2}$ adalah ternak ruminansia (ekor, standar sapi), $Y_{3}$ adalah jumlah anggota rumah tangga (jiwa), $Y_{4}$ adalah jumlah anggota rumah tangga yang bekerja (orang), $Y_{5}$ adalah umur Kepala Keluarga (tahun), $\mathrm{Y}_{6}$ adalah pendidikan formal Kepala keluarga petani (tahun).

Untuk menguji model regresi berganda di- 
Tabel 1. Petani Responden berdasar Luas Penguasaan Lahan Tanaman Pangan

\begin{tabular}{|c|c|c|c|}
\hline \multirow[t]{2}{*}{ Karakteristik Petani } & \multicolumn{3}{|c|}{$\begin{array}{c}\text { Partisipasi Petani dalam Konservasi Lahan } \\
\text { menurut Luas Penguasaan Lahan }\end{array}$} \\
\hline & $\begin{array}{c}<0,5 \text { ha } \\
\text { (37 responden) }\end{array}$ & $\begin{array}{c}\geq 0,5 \text { ha } \\
\text { (31 responden) }\end{array}$ & $\begin{array}{c}\text { Rata-rata } \\
\text { (68 responden) }\end{array}$ \\
\hline Umur (tahun) & 50 & 54 & 52 \\
\hline Jum Kel (orang) & 3 & 3 & 3 \\
\hline Kel Kerja (orang) & 2 & 2 & 2 \\
\hline Pendidikan Kepala Kel (tahun) & 5 & 6 & 6 \\
\hline Ternak Ruminansia (ekor) & 1 & 1 & 1 \\
\hline Lahan Usahatani $\left(\mathrm{m}^{2}\right)$ & 3.069 & 8.063 & 5.526 \\
\hline
\end{tabular}

Sumber: Analisis Data primer, 2011

pergunakan metode Ordinary Least Square (OLS). Model dapat diuji apakah sesuai dengan asumsi-asumsi klasik dan terhadap kesesuaian model (Greene, 2002; Gudjarati, 2003). Pengujian terhadap asumsi klasik ditujukan untuk mengetahui apakah koefisien regresi estimasi merupakan penaksir tak bias yang terbaik (Best Linear Unbiased Estimator, BLUE). Jika pengujian menunjukkan adanya pelanggaran terhadap asumsi klasik, analisis akan menggunakan metode Feasible Generalised Least Squares (FGLS), yaitu suatu model yang diperbaiki sehingga terbebas dari gangguan yang semula ditemui. Pengujian kesesuaian model dilakukan meliputi uji F, R², dan uji t individual.

Selanjutnya, hasil penelitian model konservasi lahan untuk meningkatkan partisipasi petani dalam melaksanakan konservasi lahan spesifik lokasi di Sub DAS Solo Hulu sesuai persamaan 2 dan 4 dapat dirumuskan:

$\mathrm{IKK}_{2}^{\prime}=\mathrm{f}\left(\mathrm{X}_{\mathrm{i}}^{\prime}, \mathrm{Y}_{\mathrm{i}}^{\prime}\right)$

$X_{i}^{\prime} ; i=1$ sampai dengan $\leq 10$

$Y_{i}^{\prime} ; i=1$ sampai dengan $\leq 6$

Keterangan: $\mathrm{IKK}_{2}{ }^{\prime}$ adalah model konservasi lahan untuk meningkatkan partisipasi petani dalam melaksanakan konservasi lahan spesifik lokasi di Sub DAS Solo Hulu, $X_{i}^{\prime}$ adalah tingkat partisipasi petani dalam konservasi lahan sesuai konsep IKK yang senyatanya dilaksanakan oleh para petani menurut hasil penelitian yang mencapai kriteria rendah atau tidak baik; dan $Y_{i}^{\prime}$ adalah faktor-faktor yang berpengaruh nyata terhadap IKK menurut hasil analisis regresi sesuai persamaan 3 dan 4 .

\section{HASIL DAN PEMBAHASAN}

\section{Petani Responden}

Semua responden adalah petani tanaman pangan yang dapat dibedakan atas para petani yang menguasai lahan $<0,5$ ha dan para petani yang memiliki lahan $\geq 0,5$ ha (Tabel 1 ).

Sebagaimana data tersaji pada Tabel 1, rata-rata para petani memelihara ternak sapi, hal ini sangat membantu petani dalam mendapatkan tambahan pendapatan serta sumber pupuk organik. Luas penguasaan lahan terbatas, para petani pada umumnya membudidayakan tanaman pangan sebagai petani pemilik dan penggarap. Tercatat 66 petani adalah pemilik penggarap, dua orang petani sebagai penyakap, dan seorang petani pemilik pengarap dapat menambah luas penguasaan lahannya dengan menyewa.

\section{Partisipasi Petani dalam Konservasi Lahan}

Hasil pengukuran partisipasi para petani dalam konservasi lahan yang menggunakan 10 parameter, rata-rata partisipasi para petani dalam konservasi lahan berada pada katagori sedang yaitu mencapai 69,63 persen (Tabel 2).

Kegiatan konservasi lahan dengan pembuatan teras pada lahan yang miring $\left(\mathrm{X}_{1}\right)$ telah dilaksanakan dengan baik oleh para petani, hal ini sejalan dengan penjelasan Bastos, G.S. et al., (2001), Suripin (2004), dan Chouinard, H.H et.al., (2008) bahwa telah sejak lama terdapat penghargaan atas lahan dari para petani dan pihak-pihak lainnya atas lahan sebagai sumberdaya penting dalam produksi pertanian yang 
Tabel 2. Partisipasi Para Petani dalam Konservasi Lahan sesuai IKK

\begin{tabular}{crrr}
\hline $\begin{array}{c}\text { Kegiatan } \\
\text { Konservasi }\end{array}$ & \multicolumn{3}{c}{$\begin{array}{c}\text { Partisipasi Petani dalam Konservasi Lahan } \\
\text { menurut Luas Penguasaan Lahan }\end{array}$} \\
\cline { 2 - 4 } & $\mathbf{2 0 , 5}$ ha (37 KK) (\%) & $\mathbf{2 0 , 5}$ ha (31 KK) (\%) & Rata-rata (68 KK)(\%) \\
\hline$X_{1}$ & 85,00 & 79,92 & 82,46 \\
$X_{2}$ & 42,07 & 43,01 & 42,54 \\
$X_{3}$ & 100,00 & 100,00 & 100,00 \\
$X_{4}$ & 100,00 & 100,00 & 100,00 \\
$X_{5}$ & 55,95 & 60,00 & 57,97 \\
$X_{6}$ & 29,19 & 32,97 & 31,08 \\
$X_{7}$ & 51,18 & 39,97 & 45,58 \\
$X_{8}$ & 84,08 & 86,02 & 85,05 \\
$X_{9}$ & 78,24 & 85,81 & 82,02 \\
$X_{10}$ & 69,41 & 69,74 & 69,57 \\
Rata-rata & 69,51 & 69,74 & 69,63 \\
\hline
\end{tabular}

Sumber: Analisis Data Primer, 2011

Keterangan: KK adalah Kepala Keluarga, $\mathbf{X}_{\mathbf{1}}$ adalah pembuatan teras/galengan pada lahan miring, $\mathbf{X}_{\mathbf{2}}$ adalah penanaman tanaman atau rumput penguat teras, $\mathbf{X}_{3}$ adalah pengolahan lahan sesuai garis contour, $\mathbf{X}_{\mathbf{4}}$ adalah pembudidayaan tanaman sesuai garis contour, $\mathbf{X}_{\mathbf{5}}$ adalah pergiliran tanaman semusim, $\mathbf{X}_{\mathbf{6}}$ adalah penanaman tanaman tahunan pada lahan yang kemiringannya tinggi, $\mathbf{X}_{\mathbf{7}}$ adalah penggunaan mulsa atau pupuk kandang, $\mathbf{X}_{\mathbf{8}}$ adalah pemeliharaan teras atau galengan, $\mathbf{X}_{\mathbf{9}}$ adalah pembuatan saluran drainase, dan $\mathbf{X}_{\mathbf{1 0}}$ adalah rasa tanggung jawab petani atas konservasi lahan.

harus dijaga kelestariannya. Dalam hal ini bantuan dari Pemerintah Indonesia untuk melalui lintas sekoral dilakukan banyak sejak tahun 1970an (Tiastono, 2006).

Penanaman tanaman atau rumput penguat teras $\left(X_{2}\right)$ dan penanaman tanaman tahunan pada lahan yang kemiringannya tinggi $\left(X_{6}\right)$ masih dilaksanakan pada tingkat yang rendah. Hal tersebut bagi petani tanaman pangan dengan luas lahan yang terbatas, mereka bersikap seperti penjelasan (Dariah, A. et al. dalam Suwarto (2010) bahwa penanaman tanaman tahunan atau rumput penguat teras akan mengurangi luas lahan yang ditanami tanaman pangan.

Pengolahan lahan sesuai garis contour $\left(X_{3}\right)$ dan pembudidayaan tanaman sesuai garis contour $\left(\mathrm{X}_{4}\right)$ telah dilaksanakan secara baik oleh para petani, hal tersebut sejalan dengan pada umumnya para petani telah membuat teras pada lahannya yang miring, sehingga pelaksanaan pengolahan lahan dan pembudidayaan tanaman sesuai garis contour mudah dilaksanakan. Pelaksanaan konservasi lahan tersebut sejalan dengan pelaksanaan konservasi lahan di wilayah lahan kering kabupaten Gunung Kidul, wilayah tetangga kabupaten Wonogiri (Suwarto, 2007).
Pergiliran tanaman semusim $\left(\mathrm{X}_{5}\right)$ belum sepenuhnya dilaksanakan dengan baik oleh para petani dengan baik, hingga parameter ini baru mancapai tingkat sedang. Sebagain petani tidak menanam tanaman kacang-kacangan yang dapat mengikat $\mathrm{N}_{2}$ bebas dari udara dalam melakukan pergiliran tanaman dalam satu tahun. Hal tersebut dapat disebabkan karena pertimbangan tertentu, misalnya pemilikan bahan tanaman, pengalaman sebelumnya berkenaan dengan harga produk, atau penguasaan teknologi budidaya.

Penggunaan mulsa atau pupuk kandang $\left(X_{7}\right)$, pelaksanaannya masih rendah, hal tersebut menunjukkan perluya pemberdayaan kepada para petani untuk melaksanakan pemupukan organik secara baik. Sebagaimana data pada Tabel 1, rata-rata petani sudah memiliki ternak sapi, tetapi setelah ditelusuri ternyata tidak merata kepemilikannya. Sebanyak 37 petani atau 54 persen dari responden tidak memelihara sapi. Bagi para petani yang tidak memelihara sapi atau ternak lain setara sapi maka akan kesulitan dalam menyediakan mulsa atau pupuk organik dalam memelihara lahannya. Pentingnya penggunaan bahan organik dilaporkan Idjudin, A.A. et al., (2006) dalam penelitiannya mengatasi lahan kritis di kabupaten Gunung 
Kidul yang dilakukan selama 4,5 tahun dengan pemberian 5 -10 ton ha-1 pupuk organik yang dikombinasikan dengan perlakuan lainnya berhasil menanggulangi lahan kritis.

Pelaksanaan pemeliharaan teras atau galengan $\left(\mathrm{X}_{8}\right)$ dan pemeliharaan saluran drainase $\left(X_{9}\right)$ telah dilaksanakan oleh para petani secara baik. Hal tersebut menyiratkan bahwa para petani sebenarnya berupaya melaksanakan konservasi lahan, terutama yang mudah dilaksanakan dengan tenaga kerja sendiri. Mengenai rasa tanggung jawab para petani dalam konservasi lahan $\left(X_{10}\right)$ yang baru mencapai tingkat sedang, hal tersebut karena sebagian para petani masih mengharapkan adanya uluran tangan pihak pemerintah untuk melaksanakan konservasi lahan secara baik. Hal tersebut bisa dimengerti jika bantuan pemerintah tersebut terhadap pekerjaan yang berat, memerlukan biaya mahal seperti pembuatan teras. Para petani berlahan luas juga menerima bantuan sharing pembiayaan di negara maju dalam melakukan konservasi lahan (Batos, G.S. et al., (2001) dan Chouinard, H.H. et.al., (2008).

Sesuai hasil penelitian, maka tingkat partisipasi para petani dalam konservasi lahan pada parameter yang telah mencapai katagori tinggi seyogyanya dapat terus dipertahankan, sebaliknya pencapaian partisipasi yang masih rendah hingga sedang maka harus ditingkatkan.

\section{Faktor-faktor Sosial Ekonomi Petani yang Berpengaruh terhadap IKK}

Pengaruh karakteristik petani terhadap IKK disajikan data hasil analisis regresi berganda pada Tabel 3. Model regresi yang disusun dapat dipergunakan, dalam hal ini F-tabel nyata pada taraf kesalahan $1 \%$, tidak mengandung multicollinearity yang serius. Nilai korelasi antarvariabel bebas terbesar 0,6975 yaitu antara jumlah anggota keluarga yang bekerja dengan jumlah anggota keluarga. Nilai adjusted $\mathrm{R}^{2}$ sebesar 0,2251, model mengindikasikan adanya heteroscedastici$t y$, hal tersebut ditunjukkan oleh hasil test heteroscedasticity pada keempat model signifikan. Untuk mengatasi pelanggaran terhadap kaidah homoskedastisitas tersebut dilakukan dengan menggunakan regresi model heteroscedasticity. Nilai Likelihood Ratio (LR) nyata pada taraf kesalahan 5 persen, dan ke dua model heteroscedasticity, yaitu model varlin dan stdlin dapat memperbaiki model OLS. Model heteroscedasticity dengan varlin mendapatkan hasil koefisien regresi nyata terbanyak yaitu 4 variabel, dipergunakan untuk menjelaskan model regresi.

Sebagaimana hasil analisis, jumlah anggota keluarga yang bekerja meningkatkan partisipasi para petani dalam konservasi lahan, hal tersebut mudah dipahami. Banyaknya tenaga kerja yang dapat bekerja maka peluang untuk dapat melaksanakan konservasi lahan juga semakin besar, hal ini karena para petani dapat melakukan konservasi lahan dengan tenaga kerja sendiri, tidak harus mengupah yang dapat meningkatkan biaya produksi dalam usahatani.

Umur petani tidak berpengaruh terhadap

Tabel 3. Hasil Analisis Faktor-faktor yang Mempengaruhi Kegiatan konservasi Lahan di Sub DAS Solo Hulu

\begin{tabular}{|c|c|c|c|c|}
\hline \multirow[b]{2}{*}{ Variabel } & \multicolumn{2}{|c|}{ OLS } & \multicolumn{2}{|c|}{ Heteros. (Varlin) } \\
\hline & Koef. Reg. & t-hit. & Koef. Reg. & t-hit. \\
\hline Umur (Tahun) & $0,40384 \mathrm{E}-01$ & 0,3767 & $-0,35140 \mathrm{E}-02$ & $-0,1071$ \\
\hline Jumlah anggota RT (jiwa) & $-0,59965$ & $-0,4550$ & $-0,51031$ & $-0,4692$ \\
\hline Jumlah anggota RT yang bekerja (orang) & 3,5893 & 1,926 & $2,8440 *$ & 2,508 \\
\hline \multicolumn{5}{|l|}{ Pendidikan formal i (tahun) } \\
\hline Ternak ruminansia (ekor) & $1,0643^{*}$ & 2,440 & $0,77350^{* *}$ & 6,748 \\
\hline \multirow[t]{2}{*}{ Luas penguasaan lahan (ha) } & $3,8144^{* *}$ & 3,355 & $2,9061^{* *}$ & 5,994 \\
\hline & $-0,96395 \mathrm{E}-04$ & $-0,4346$ & $0,21405 \mathrm{E}-03^{* *}$ & 3,510 \\
\hline Konstanta & $1,752^{* *}$ & 7.265 & $56.768^{* *}$ & 14.53 \\
\hline \multirow[t]{2}{*}{ adjusted $\mathrm{R}^{2}$} & 0,2251 & & 0,2251 & \\
\hline & F-hitung & $475,48^{* *}$ & & \\
\hline
\end{tabular}

Sumber: Analisis Data Primer, 2011

Keterangan: $*$ ) $=$ nyata pada $\alpha=5 \%, * *$ ) $=$ nyata pada $\alpha=1 \%, \mathrm{RT}=$ Rumah Tangga 
penerapan konservasi lahan, umur dapat berkenaan dengan pengalaman para petani dalam konservasi lahan. Rata-rata para petani responden telah berumur 52 tahun, pada umumnya para petani telah menerima sosialisasi usahatani termasuk konservasi lahan sejak lama, atau sejak kecil, karena pada umumnya mereka hidup dan dibesarkan dalam keluarga petani.

Jumlah anggota RT tidak berpengaruh terhadap partisipasi dalam konservasi lahan, di lain pihak jumlah anggota RT yang bekerja berpengaruh terhadap partisipasi para petani dalam konservasi lahan, dalam hal ini rata-rata anggota RT tiga orang dan rata-rata tenaga kerja yang bekerja adalah dua orang. Hasil penelitian ini menunjukkan semakin banyak anggota keluarga yang bekerja maka pelaksanaan konservasi lahan akan semakin baik. Hal tersebut diduga sebagian penduduk menggunakan waktu utamanya untuk bekerja pada sektor pertanian. Banyaknya anggota RT bekerja maka diperoleh pendapatn yang lebih besar, di antaranya dapat dipergunakan untuk pekerjaan on farm seperti melakukan konservsi lahan.

Pendidikan formal meningkatkan partisipasi para petani dalam konservasi lahan. Hal tersebut diduga dengan semakin tinggi tingkat pendidikan petani, waka wawasan para petani juga meningkat, termasuk meningkatnya kesadaran dalam melaksanakan konservasi lahan. Sejalan dengan hal tersebut Asafu-Adjaye (2008) menjelaskan bahwa persepsi pendidikan mempengaruhi persepsi individu terhadap suatu obyek. Lebih jauh dijelaskan oleh Mugnisyah et al., (2001) bahwa tingkat pendidikan mempengaruhi pekerjaan on farm, yaitu dalam menentukan input produksi.

Pemilikan atau penguasaan ternak ruminansia meningkatkan partisipasi para petani dalam konservasi lahan. Para petani pemelihara ternak menghasilkan kotoran ternak yang kemudian dipergunakan untuk membuat pupuk kandang atau pupuk organik yang penting dalam konservasi lahan. Di samping itu, para petani peternak pada umumnya juga menanam rumput, misalnya rumput gajah pada terasteras (galengan) lahan usahataninya, sehingga para petani tersebut dapat memperoleh pakan ternak dari rumput dan tanaman penguat teras lahan usahataninya. Mengenai pertimbangan para petani, Lichtenberg, E., and R. SmitthRamirez (2010) menjelaskan bahwa di Amerika Serikat jumlah ternak yang dipelihara peternak menentukan pilihan petani untuk bergabung dalam kerjasama pembiayaan untuk program konservasi lahan.

Luas penguasaan lahan juga meningkatkan partisipasi para petani dalam konservasi lahan. Para petani kecil mempunyai kebutuhan utama bahan pangan, fenomena tersebut nampak jelas di masyarakat, bahwa para petani kecil, walaupun lahan usahataninya berkemiringan tinggi, pada umumnya masih menggunakan lahan tersebut untuk tanaman pangan. Jika petani berlahan luas, maka para petani dapat membudidayakan tanaman sesuai kelas kemampuan lahan (Suwarto, 2007). Terdapatnya peluang bagi para petani bekerja pada off farm dan non farm diduga akan menurunkan tekanan penduduk atas lahan, sehingga lambat laun para petani akan menggunakan lahan secara bijaksana, sesuai kemampuan lahan. Pada umumnya banyak ahli seperti Asafu-Adjave, J. (2008), Chang, H. et.al, (2009), dan Lichtenberg, E. et.al., (2010) menjelaskan bahwa luas lahan adalah faktor penting yang mempengaruhi petani melaksanakan kegiatan konservasi lahan

\section{Model IKK Spesifik Lokasi yang Sesuai un- tuk Meningkatkan Partisipasi Petani dalam Konservasi Lahan}

Model spesifik lokasi yang berguna untuk meningkatkan partisipasi para petani dalam konservasi lahan dapat diketahui dari hasil valuasi mengenai tingkat partisipasi petani dalam konservasi lahan (Tabel 2) dengan faktorfaktor yang berpengaruh nyata dalam partisipasi petani dalam konservasi lahan (Tabel 3). Dari Tabel 2 kita ketahui bahwa kegiatan konservasi lahan yang masih rendah hingga sedang menurut konsep IKK yaitu: penanaman tanaman rumput penguat teras, penggunaan mulsa atau pupuk kandang, dan pergiliran tanaman semusim. Selanjutnya faktor-faktor yang berpengaruh nyata meningkatkan partisipasi petani dalam konservasi lahan sesuai hasil analisis regresi yaitu: jumlah anggota RT yang bekerja 
(orang), pendidikan formal petani (tahun), ternak ruminansia (ekor), dan luas penguasaan lahan (ha)

Oleh karena itu, maka model yang baik untuk dapat meningkatkan partisipasi dalam konservasi lahan yaitu membantu memberdayakan para petani agar senantiasa mendapatkan penidikan (non formal) meliputi usahatani berkelanjutan, memberdayakan para petani untuk dapat memiliki atau memelihara ternak ruminansia, serta memberdayakan agar penguasaan lahannya mencapai luasan optimal, sehingga dapat mempergunakan lahannya sesuai kemampuan lahan. Dalam hal partisipasi petani dalam konservasi lahan kiranya dapat dilakukan pemberdayaan petani dalam penanaman tanaman rumput penguat teras, penggunaan mulsa atau pupuk kandang, dan pergiliran tanaman semusim di antaranya menggunakan tanaman legumenoseae.

\section{SIMPULAN}

Rata-rata para petani responden berpartisipasi pada tingkat sedang dalam konservasi lahan. Penanaman tanaman atau rumput penguat teras, penanaman tanaman tahunan pada lahan yang kemiringannya tinggi, dan penggunaan mulsa atau pupuk kandang baru dilaksanakan pada tingkat rendah. Hal tersebut karena para petani yang kebanyakan berlahan sempit sempit tersebut utamanya berupaya dapat semaksimal mungkin menanam tanaman pangan pada lahan usahataninya. Di samping itu, sebagian besar petani tidak memiliki ternak sapi sehingga kesulitan mendapatkan mulsa atau pupuk kandang.

Pergiliran tanaman semusim pelaksanaannya pada tingkat sedang, sebagaian petani belum mengintegrasikan tanaman kacang-kacangan dalam pergiliran tanaman, hal ini dapat disebabkan pertimbangan situasional, seperti penguasaan bahan tanaman, harga, atau pertimbangan teknis budidaya. Pembuatan teras atau galengan pada lahan miring, pengolahan lahan sesuai garis contour, pembudidayaan tanaman sesuai garis contour, pemeliharaan teras atau galengan, dan pembuatan saluran drainasi telah dilaksanakan secara baik oleh para petani.
Dalam hal ini dapat diketahui bahwa pelaksanaan pekerjaan konservasi lahan yang menggunakan tenaga kerja manusia dilakukan secara baik oleh para petani.

Sesuai pencapaian pelaksanaan konservasi lahan bagi para petani, faktor-faktor yang berpengaruh nyata terhadap partisipasi para petani dalam konservasi lahan yaitu jumlah anggota Rumah Tangga yang bekerja (orang), pendidikan formal petani (tahun), ternak ruminansia (ekor), dan luas penguasaan lahan (ha). Dalam hal ini umur petani dan jumlah anggota Rumah Tangga tidak berpengaruh nyata dalam partisipasi petani dalam konservasi lahan.

Sesuai hasil penelitian, model yang baik untuk dapat meningkatkan partisipasi petani dalam konservasi lahan meliputi pengelolaan atas faktor-faktor yang berpengaruh nyata dalam meningkatkan partisipasi petani dalam konservasi lahan yaitu: pendidikan, pemeliharaan ternak ruminansia, dan luas penguasaan lahan, serta pemberdayaan petani atas pencapaian parameter IKK yang masih rendah yaitu: pemberdayaan petani dalam penanaman tanaman rumput penguat teras, penggunaan mulsa atau pupuk kandang, dan pergiliran tanaman semusim diantaranya menggunakan tanaman legumenoseae.

Langkah-langkah penting dalam pemberdayaan petani wilayah penelitian yaitu untuk dapatnya para petani mengintegrasikan ternak ruminansia dalam usahatani, dalam jangka pendek mungkin dapat diatasi dari subsidi atau kredit produksi dari pemerintah, dan penyediaan jasa pendidikan non formal. Sejalan dengan penguasaan lahan yang terbatas bagi para petani, untuk menurunkan tekanan penduduk atas lahan sehingga petani dapat menggunakan lahan secara bijaksana, perlu diteliti pengembangan dan pemberdayaan petani ke arah off farm, dan juga non farm, sehingga menambah lapangan pekerjaan dan pendapatan bagi para petani

\section{DAFTAR PUSTAKA}

Arsyad, S. 2006. Konservasi Tanah dan Air. Bogor: IPB Press. 
Asafu-Adjaye, J. 2008. Factors Affecting the Adoption of Soil Conservation Measures: A Case Study of Fijian Cane Farmers. Journal of Agriculture and Resource Economics. 33 (1): 99-17. Logan, UT, United State. Western Agriculture Economics Association.

Bastos, G.S. and E. Lichtenberg. 2001. Priorities in Cost Sharing and Water Conservation: A Revealed Preference Study. Land Economics. 77 (4): 533-547 ISSN 0023-769 (C) 2001 by the Board of Regents of the University of Wisconsin System.

BPS. 2008. Wonogiri dalam Angka 2007. Wonogiri: Badan Pusat Statistk Wonogiri dan BAPPEDA Kabupaten Wonogiri.

BPS. 2001. Statistik Indonesia. Jakarta: Badan Pusat Statistik Indonesia.

Chang, H., and R.N. Boisvert. 2009. Distinguishing between Whole-Farm vs. PartialFarm Participation in the Conservation Reserve Program. Land Economics. 85 (1): 144-161 ISSN 0023-769; E-ISSN 1543-8325 (C) 2009 by the Board of Regents of the University of Wisconsin System.

Chouinard, H.H., T. Paterson, P.R. Wandschneider, and A.M. Ohler. 2008. Will Farmers Trade Profits for Stewardship? Heterogeneous Motivations for Farm Practice Selection. Land Economics. 84(1): 66-82 ISSN 0023-769; E-ISSN 1543-8325 by The Board of Regents of the University of Wisconsin System.

Darwawan, A. 2009. Evaluasi Penggunaan Lahan Berdasarkan Konsep Fasies Gunung Api untuk Menunjang Peraturan Zona dalam Tata Ruang (Studi Kasus Wilayah Sub-DAS Keduang, DAS Bengawan Solo Hulu, Kabupaten Wonogiri, Propinsi Jawa Tenngah). Buletin Geologi Tata Lingkungan (Buletin of Environmental Geology): 19 (2): 5--59

Dariah, A., A. Rachman, dan U. Kurnia. 2004. Erosi dan Degradasi Lahan Kering di Indonesia. Dalam Teknologi Konservasi Tanah pada Lahan Kering. Pusat Penelitian dan Pengembangan Tanah dan Agroklimat. Bogor: 11-34. Badan Penelitian dan Pengembangan Pertanian, Departemen Pertanian.

Dariah, A., H. Subagyo, C. Tafakresnanto, dan S. Marwanto. 2004b. Kepekaan Tanah terhadap Erosi. Dalam Teknologi Konservasi Tanah pada Lahan Kering. Pusat Penelitian dan Pengembangan Tanah dan Agroklimat. Bogor: 1-10. Badan Penelitian dan pengembangan Pertanian, Departemen Pertanian.

Holden, S.T., K. Deininger, and H. Ghebru. 2009. Impacts of Low-Cost Land Certification on Investment and Productivity. American Journal of Agro Economic. 91 (2):359-373.

Idjudin, A.A, Subroto, Ps, dan S. Marwanto. 2006. Pengaruh Teknik Konsrvasi terhadap Perbaikan Lahan Kritis. Jurnal Tanah dan Air: 7 (1): 92-100. Yogyakarta. Jurusan Ilmu Tanah UPN.

Greene, W.H. 2002. Econometric Analysis. New York, Toronto, Singapore. Macmillan Publishing Company.

Gudjarati, D.N. 2003. Basic Econometrics, Forth Ed. Boston: Mc Graw Hill.

Lichtenberg, E., and R. Smitth-Ramirez. 2010. Slippage Conservation Cost Sharing. American Journal of Agroeconomy. 93 (1): 113129.

Lynch, L. and W.N. Musser. 2001. A Relative Efficiency Analysis of Farmland Preservation Programs. Land Economics. 77(4): 577-594 ISSN 0023-769 by The Board of Regents of the University of Wisconsin System.

M.K.McLeod and Rahmianna. 2009. Upland Soils for Crop Production in Indonesia-Constraints and Opportunities. Proceedings Internasional Seminar, Upland for Food Security, November 7-8 2009, Purwokerto 
(Indonesia): 25-33. Faculty of Agriculture, Jenderal Soedirman University.

Morgan, RPC. 2005. Soil Erotion and Conservation. Third Edition. Main Street, Malden, MA 02148-5020. USA: Balckwell Publishing.

Mugniesyah, S.S.M. and K. Mizuno. 2001. Gender, Poverty and Peasant Houshold Survival Strategies A Case Study in Dry Land Village in West Java. Proceedings of The 1st Seminar, Toward Harmonization between Development and Environmental Conservation in Biological Production, February 2123, 2001. Japan:63-78. Yayoi Auditorium Graduate School of Agricultural and Life Sciences, The University of Tokyo.

Mukhlisin, M. 2007. Envronmental Study Impact of Sediment Flushing on Downstream Area Case Study: Planning of Sediment Flushing on Gadjah Mungkur DAM, Wonogiri, Central Java. Semarang: Wahana TEKNIK SIPIL. 12 (2): 139-149

Nasution, M. 2004. Diversifikasi Titik Kritis Pembangunan Pertanian Indonesia. Dalam Pertanian Mandiri. Pandangan Strategis Para Pakar untuk Kemajuan Pertanian Indonesia. Jakarta: Penebar Swadaya.

Pakpahan, A., Syafaat, A. Purwoto, H.P. Saliem, dan G.S. Hardono, 1992. Kelembagaan Lahan dan Konservasi Tanah dan Air. Pusat Penelitian Sosial Ekonomi Pertanian, Badan Penelitian dan pengembangan Pertanian. Bogor.

Pande, V.C., R.S. Kurothe, H.B. Singh, and S.P. Tiwari. 2011. Incentives for Soil and Water on Farm in Ravines of Gujarat: Policy Implication for Future Adoption. Agricultural Ecomomics Research Review. Vol.24 January-June 2011. Pp 109-118
Pramono, B. I. 2010. Laporan Hasil Penelitian Peningkatan Produktivitas Lahan Miring Berbahan Induk Kapur dengan Sistem Agroforestri untuk Ketahanan Pangan dan Pengendalian Erosi, program Intensif Riset Terapan. Kementerian Kehutanan Badan Penelitian dan pengembangan Kehutanan, Balai Penelitian Kehutanan Solo.

Santoso, D., J. Purnomo, I.G.P. Wigena, dan E. Tuherkih. 2004. Teknologi Konservasi Tanah Vegetatif. Dalam Teknologi Konservasi Tanah pada Lahan Kering. Pusat Penelitian dan Pengembangan Tanah dan Agroklimat. Bogor: 77-108. Badan Penelitian dan Pengembangan Pertanian, Departemen Pertanian.

Singarimbun, M., 1989. Metode dan Proses Penelitian. Singarimbun, M., dan S. Effendi. (eds). Metode Penelitian Survai. LP3ES, Jakarta:1-15.

Suripin. 2004. Pelestarian Sumber Daya Tanah dan Air. Yogyakarta: Andi.

Tiwari, K.R., B.K. Sitaula, I.L.P. Nyborg, and G.S. Paudel. 2008. Determinants of Farmers' Adoption of Improved Soil Conservation Technology in Middle Mountain Watershed of Central Nepal. Enveronmental Management. 42: 210-222. DOI 10.1007/ s00267-008-9137-z (C) Springer Science + Business Media, LLC 2008.

Triastono, J. 2006. Pengaruh Penerapan Teknologi Konservasi Crop-Livestock System (CLS) terhadap Usahatani di DAS Serang Hulu, Kabupaten Boyolali. Disertasi, Sekolah Pascasarjana Universitas Gadjah Mada. Yogyakarta (unpublished). 